\title{
IAMJ
}

INTERNATIONAL

AYURVEDIC

MEDICAL JOURNAL

\section{UNDERSTANDING THE CONCEPT OF PATALA \& DRISHTI}

\author{
Tarun Kumar Dwibedi ${ }^{1}$, Veerayya R Hiremath ${ }^{2}$, Shashikala K ${ }^{3}$, Gururaj N ${ }^{4}$ \\ ${ }^{1}$ P.G Scholar, ${ }^{2}$ Professor and HOD, ${ }^{3}$ Asso. Professor, ${ }^{4}$ Asst. Professor. Dept. Shalakya Tantra SJGAMC, \\ Koppal, Karnataka, India
}

Corresponding Author: dr.tarun52@gmail.com

\section{https://doi.org/10.46607/iamj4408102020}

(Published online: October 2020)

Open Access

(C) International Ayurvedic Medical Journal, India 2020

Article Received: 27/09/2020 - Peer Reviewed: 02/10/2020 - Accepted for Publication: 04/10/2020

\section{A) Check for updates}

\section{ABSTRACT}

Language is the base of communication. Communication is made to understand and learn the mind and imagination. Ayurveda, the ancient life science is full of terminologies. To treat any disease, one should have thorough knowledge regarding those terminologies and their multiple meanings used in different contexts. A very little description of Drishti and Patala are available in the classical literature regarding its measurement, shape, size and Panchabhoutiktwa, which is not sufficient to confine Drishti and Patala to any one part of eye. By analyzing different quotations of classical literature, we have tried to correlate the term Drishti and Patala to the structures of eyeball. As the meaning suggests the Patala is a covering, which covers the Drishti. In addition, based on the Dhatu Ashraya on four Patala of eyeball, the cornea with aqueous, the Lens with uveal tract, the posterior sclera and the retina with optic nerve can be considered as the Prathama, Dwitiya, Tritiya and Chaturtha Patala respectively. Pramana of Drishti suggests it as the fovea. Drishti is the central cornea, based on instillation of Aschyatono. Drishti is constricted and dilated in sun and in shadow or dim light. This refers to change in diameter and thickness of Drishti. Therefore, Drishti is pupillary aperture and lens. The Drishti can be the refractive media, visual pathway and retina of eyeball as Avyaktadarshana, Vramita Darshana are the symptom of Timira Roga. The Shadvida Roopa of Linganasha can be compared with the different stages of nuclear cataract. So, the Drishti can be the lens. The central cornea, pupillary aperture and the lens can be considered as Drishti, as the opacity near the Drishti produces loss of vision. The ancient surgical procedure of Sleishmika Linganasha (cataract) sug- 
gests Lekhana Karma over the Drishti. This is to be done on Drishti until vision is achieved. The symptom of Drishtigata Roga is similar to the symptoms like day blindness, night blindness, blurred vision, distorted vision (Avyaktadarshana, Vramita Darshana) etc. are also the symptoms of retinitis pigmentosa, retinitis and other pathology of retina. Therefore, Drishti is retina, fovea and optic nerve. Hence, the Drishti cannot be a single structure, rather Drishti is the refractive pathway and refractive media of eyeball.

Keywords: Drishti, Patala, Aschyatono, Avyakta Darshana, Vramita Darshana, Drishtigata Roga, Shadvida Roopa Of Linganasha, Sleishmika Linganasha.

\section{INTRODUCTION}

Shalakya Tantra is a specialized branch among Astanga-Ayurveda, which is dealing with the disease of Urdhwajatru or disease above the clavicle ${ }^{[1]}$. Maharishi Sushruta has described the gross structure of Netra in detail. Nineteen chapters of Sushruta Samhita Uttaratantra are dealing with Netra Rachana Shareera, Kriya Shareera, disease of Netra, treatment of Netra Roga and Kriya Kalpa (Topical treatment) of Netra Roga. This represents the importance of Netra in ancient life science. Netra is the Gyanendriya responsible for visual perception. The perception process of vision is incomplete in the absence of Atma, Mana, Indriya, and Indriyartha ${ }^{[2]}$. Dristi is the functional unit of the vision process. In the available literatures, the term Patala \& Drishti are not specified. Hence it is a matter of debate. Ayurveda, the ancient life science is full of terminologies. To learn and to treat any disease one should have thorough knowledge regarding those terminologies and their multiple meanings used in texts.

A very little description of Patala \& Drishti is available in the classical literature regarding its measurement, shape, size and Panchabhoutiktwa, which are not sufficient to confine Patala \& Drishti to any one part of eyeball. By referring the available literature, we have tried to correlate the term Patala \& Drishti to tunic/layers of eyeball, refractive media, refractive pathway, retina, fovea and optic nerve of the eyeball.

\section{Description}

Drishti is derived from "Drish "Dhatu and "Ktin" Pratyaya. It literary means "to see things" or it is the vision process. If the Dosha seats on the Prathama Patala of Drishti (Yasya Drustau Byabasthita), there will be Avyakta Darshana ${ }^{[3]}$. It means in Prathama
Patala Gata Timira the Dosha has to seat over the Prathama Patala "of Drishti". So, Netra as a whole is Drishti. Drop wise administration of medicines to the open eye, from the height of two Angula, is known as the Aschyatono ${ }^{[4]}$. This is a Netra-Kriyakalpa explained in different literature of Ayurveda. The Aschyatono process is even more specified by Sarangadhara Samhita. According to him, the administration of medicine drops on the Drung-Madhye, ${ }^{[5,6]}$ is Aschyatono. The meaning of 'Drung-Madhye' is over the central cornea or above the pupillary aperture on the cornea or above the lens on the cornea. This suggests Drishti is Cornea, Pupillary aperture or the lens. Vivara means a hole or an aperture. Drishti is surrounded by Patala ${ }^{[3]}$ and it is looking like Vivarakriti from outside. In font of Drishti, an aperture is likely to appear ${ }^{[3]}$. Before the lens, the pupillary aperture is present and before the retina, the pupillary aperture along with the lens is present. Therefore, Drishti may be the anterior segment, posterior segment, pupillary aperture, lens and retina. Drishti-Mandala is constricted and dilated in Sun and in shadow respectively ${ }^{[7]}$. By this quotation, Drishti can be taken as the pupillary aperture or lens as it's diameter and thickness varies with the intensity of light. Therefore, the Drish$t i$ is pupillary aperture or lens. Shape and size of the Drishti is like a Masooradala, it means a lentil like ${ }^{[3]}$. The lentil is biconvex. It reveals Drishti as biconvex lens.

It is described that Netra has six Patala out of which two Vartma Patala and four Akshi Patala [1]. The Timira Roga seats in those four Patala and Timira is the disease of Drishti Mandala. Therefore, it can be 
told that Drishti and Patala have some similarities. We have tried to analyze Patala as follows.

- Prathama Patala is Teja Jala Ashrita ${ }^{[1]}$. Cornea is avascular, so it gets nutrition from the aqueous and the tear film protects the cornea and lubricates it. Aqueous contains $99.9 \%$ water (Jala) ${ }^{[8]}$. The stromal layer of cornea bears $90 \%$ of total cornea, which is in a state of dehydration, maintaining the transparency of the cornea ${ }^{[9]}$. Dehydration cannot possible without the Agni-Mahabhoota. Agni means Teja. If Dosha seats in Prathama Patala then there will be Avyakta Darshana, which can be refractive error. Any pathology in Cornea also causes refractive error. Hence, the cornea can be the Prathama Patala and any abnormality of this structure may lead to refractive error that is Timi$r a$, the disease of Drishti. Therefore, the Prathama Patala is Cornea.

- Dwitiya Patala is Mamsashrita ${ }^{I}$. Lens is suspended by the suspensory ligaments from the ciliary body. Cilliary body has ciliary muscle ${ }^{[10]}$. The iris has pupillae muscle ${ }^{[10]}$, which is the continuation of ciliary body and choroid. Abnormality in the ciliary muscle and Zonules or Suspensory ligament leads to abnormality of accommodation and causes refractive error ${ }^{[11]}$. The pathology of lens also causes refractive error that is Timira, the disease of Drishti.

Six extraocular muscles (EOM) are attached to each eye. Those EOM are responsible for the eye movement and are inserted into the scleral surface ${ }^{[12]}$. Strabismus is a disease caused by the faulty insertion and weakness of EOM ${ }^{[13]}$. The strabismus also causes blurring of vision ${ }^{[13]}$ and strabismic amblyopia ${ }^{[14]}$. Staphyloma can cause variation in axial length of eyeball; results in the refractive error ${ }^{[15]}$. Those can be correlated to the Avyakta Darshana and Vramita Darshana, which are the symptoms of Timira. Hence, the uveal tract along with lens can be the Dwitiya Patala. The sclera also can be correlated to Dwitiya Patala as it is Mamsashrita (EOM) and disease of sclera (Staphyloma) can cause refractive error or Timira.

- Tritiya Patala is Medashrita ${ }^{[1]}$. The posterior part of sclera is protected or surrounded by the adipose tissue and the orbital fats, which are nothing but the Meda. Staphyloma, the disease of sclera can cause refractive error and even loss of vision. Therefore, the posterior sclera can be the Tritiya Patala.

- Chaturtha Patala is Asthi-Ashrita ${ }^{[1]}$. Optic nerve is the continuation of retina and optic nerve lodges inside the bony orbit. If Dosha involved in Chaturtha Patala then there will be partial or complete loss of vision ${ }^{[16]}$. Lesion on the retina or optic nerve may lead to partial or complete loss of vision.

So, the Chaturtha Patala and Drishti are retina and optic nerve.

This can be summarized as-

- Prathama Patala - Cornea, aqueous humour.

- Dwitiya Patala - Lens with uveal tract.

- Tritiya Patala - The posterior sclera.

- Chaturtha Patala -The retina with optic nerve.

The Patala as a whole can be considered as the layers of Cornea. In the disease Savrana Sukla of Krishnagata roga, it has been told that "If the injury occurs to the Dwitiya and Tritiya Patala, it will be Yapya and asadhya respectively" [23] as Krishna mandala is the Cornea while considering the disease explained in the classical texts of Ayurved. In the complication of Savrana Sukla, the Mudga -Akruti Pidaka (Descemetocele) has been mentioned, when there is involvement

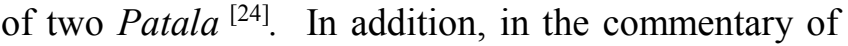
Dalhanacharya of Avrana Sukla, it has been told that "If the Avrana Sukla involves the Dwitiya Patala, the disease will be Krichhra Sadhya" [24]. Thus, the Patala clearly refers to the corneal layers. As Timira Roga seats on the Patala and Timira is the disease of Drish$t i$, so the uveal tract, the refractive-media and visual pathway can be correlated with Drishti. Netra consists of Five-Mandala. Pakshma, Vartma, Shweta, Krishna and Drishti Mandala respectively ${ }^{[1]}$. Drishti is the inner most, just behind and adjacent to Krishna Mandala. According to modern ophthalmology, sclera is the outermost and retinal layer is the inner most layer of eyeball. Therefore, Drishti can be retina. If we consider the location of Drishti adjacent to Krishna Mandala then the pupillary aperture and lens can fit into this 
concept. One-third $\left(1 / 3^{\text {rd }}\right)$ of Netra Mandala is Krishna-Mandala $(\sim 11.5 \mathrm{~mm}$ as horizontal diameter $\sim 10.6$ $\mathrm{mm}$ as vertical diameter), $1 / 7^{\text {th }}$ of Krishna-Mandala is Drishti Mandala ${ }^{[1]}(\sim 1.51 \mathrm{~mm})$ which measures the center of most sensitive part of retina called as the Fovea. Congenital loss of cones causes dayblindness ${ }^{[17]}$, which can be correlated with the symptom of Pittavidagdha Drishti ${ }^{[7]}$. Therefore, the Drishti can be correlated with retina as Pittavidagdha Drishti, a disease of Drishti.

- The pigmentary retinal atrophy causes retinitis pigmentosa with the symptom of night blindness ${ }^{[18]}$ and night blindness is also a symptom of Kaphavidagdha Drishti ${ }^{7}$. Therefore, the Drishti can be the retina as the Kaphavidagdha Drishti, a disease of Drishti.

- Harswajadya is a disease of Drishti having symptoms as day-blindness and perceiving object as smaller than the actual size (Micropsia) ${ }^{7}$. Micropsia can be caused by separation of visual cells ${ }^{[19]}$. The day blindness and visual cells separation are the diseases of retina. Therefore, Harswajadya can be correlated as the disease of retina.

- Nakulandhya (Disease of Drishti) is the Night blindness ${ }^{[7,20]}$ which is also a symptom of Retinitis pigmentosa (disease of retina) ${ }^{[18]}$. Therefore, the Drishti is retina.

- In the contraindication for Shashtrakarma in Sleishmika Linganasha, it has been told that Drishti must be examined before performing the Shashtra Karma ${ }^{[21]}$. In modern, the preoperative examination of cataract surgery includes the examination of refractive media (cornea, aqueous, iris, lens and vitreous), retina, macula and optic disc. In this preoperative examination, it is mandatory to examine the transparency of the media, type, stages and color of cataract lens, examination of fundus, its color, swelling and other pathologies of fundus, disc-cup ratio and its color etc. So here the Drishti can be lens, retina

- Shadvida Linganasha Lakshana suggests the color of Drishti because of vitiated Dosha. Those are Aruna/brownish, Nila/bluish, Seeta/whitish/ ShankhaVarna/moon-white, RaktaVarnal red-
dish/Pravala Varna, Vichitra Rupa/different color due to vitiation of Vata, Pitta, Kapha, Rakta and Tridosha respectively ${ }^{[7]}$. This can be compared with the color of lens-nucleus in different stages of nuclear cataract. Therefore, the Drishti can be correlated with lens.

- Examination of Drishti is indicated prior to the Shashtrakarma of Sleishmika Linganasha. The half-moon like spot, water droplet like spot, Pearly white spot, stable, irregular, thin, different lines and red or brown spots on Drishti with painful condition must be excluded for Shashtrakarma of Sleishmika Linganasha ${ }^{[21]}$. Those colors of the Sleishmika Linganasha are similar to the color of lens in immature, mature and hypermature cataract. This clearly reveals that the Drishti is nothing but the lens.

- Sleishmika Linganasha is Shashtra Sadhya. In this process, a Shalaka is inserted to the eyeball by puncturing it at the temporal aspect of sclera and Lekhana Karma (scarping) is done over Drishti Mandala $^{[22]}$. This refers Drishti as the Lens.

\section{Summary}

Drishti is cornea according to the administration of Aschyatono and symptom of Prathama Patalagata Timira. Drishti is the pupillary aperture according to the variation in diameter in responds to intensity of light and Dwitiya-Patalagata Timira. Drishti is the lens according to the Shadvida Roopa and Shashtrakarma of Sleishmika linganasha, variation in thickness with the intensity of light, Ashrita of Mamsa Dhatu and shape like the biconvex lentil. Drishti is retina and optic nerve according to disease of Drishti and fovea according to the disease of Drishti, the size of Drishti as compared to the size of Krishna Mandala and firefly like appearance. While correlating the Patala with the structures of eyeball the cornea and aqueous can be compared with Prathama Patala, the lens along with the uveal tract can be considered as Dwitiya Patala, the posterior sclera will be the Tritiya Patala and the retina with optic nerve can be compared with the Chaturtha Patala. While considering the disease of Krishna mandala, the layers of cornea can be referred as the Patala. 


\section{CONCLUSION}

To treat any disease, one should have thorough knowledge of terminologies and their multiple meanings used in texts. Word 'Drishti and Patala' has several meanings, according to the place where it is being used. So, we need to understand Drishti and Patala accordingly. As explained above the prathama, Dwitiya, Tritiya and Chaturtha Patala are cornea with aqueous, lens with Uveal tract, the posterior sclera and the retina with Optic nerve respectively or while considering the Krishna mandala, the layers of cornea can be referred as the Patala. The Drishti is the biconvex lens and as the disease Timira seats on Akshi Patala, the refractive pathway is Drishti. According to Ayurvedic anatomy it should be referred as the central cornea, pupillary aperture or the Lens. According to Chikitsa of Drishtigata Roga, Drishti should be correlated as lens, retina, macula and optic nerve as a whole. In modern ophthalmology, the innermost layer of eye is retina and according to Ayurved, the innermost Mandala (layer) is Drishti Mandala. By correlating the innermost layer, the Drishti is retina. Basing on the disease occurring on the Drishti Mandala the Drishti can be the retinal layer. Based on structural and functional descriptions available in Ayurveda and correlating that with modern ophthalmology, lens and retina together can be considered as Drishti.

Proper vision is impossible in the pathological state of refractive media. As per the meaning, "Drishti" is to see things. So, to see things we should have a better and well-functioning structure. From the above references, the concept of Patala and Drishti has been explained in detail to serve the mankind with the ancient treatment modalities. As a whole, we can conclude that Patala is the Cornea, Aqueous, Lens, Uveal Tract, Posterior Sclera, Retina and Optic Nerve. The Drishti is not a single structure instead; Drishti is Cornea, Pupillary Aperture, Lens, Retina, Fovea and Optic Nerve.

\section{REFERENCES}

1. Sashtri Ambika Dutta, Sushruta Samhita with Ayurve$d a$-tattva-sandipika Hindi commentary published by Chaukhambha Sanskrit Sansthan; Varanasi; Reprint 2010, Uttara Tantra 1/10-18, P.6.

2. Tripathy Brahmananda, Charaka-Samhita with Charaka-Chandrika Hindi commentary published by Chaukhamba Surbharati Prakashan; Varanasi; Reprint 2008, Sutra Sthan 11/20, P.231.

3. Sashtri Ambika Dutta, Sushruta Samhita with Ayurve$d a$-tattva-sandipika Hindi commentary published by Chaukhambha Sanskrit Sansthan; Varanasi; Reprint 2010, Uttara Tantra 7/3-6, P.40.

4. Tripathy Brahmananda, Astanga Hridayam with Nirmala Hindi commentary, Chaukhamba Sanskrit Pratishthan; Delhi; Reprint 2017, Sutrasthana 23/2-4, P.263.

5. Sashtri Parsurama, Sarangadhara Samhita with Adhamalla's Dipika and Kasirama's Gudhartha-Dipika commentary, Nirnaya Sagar Press second edition, Uttara Khanda 13/13.

6. Sashtri Laxmipatti, Yogaratnakara with Vidyotini Hindi commentary, Chaukhamba Sanskrit Sansthan, Varanasi seventh Edition 2002, Uttarardha netra Roga chikitsa Aschyatono Vidhi P. 385.

7. Sashtri Ambika Dutta, Sushruta Samhita with Ayurve$d a$-tattva-sandipika Hindi commentary published by Chaukhambha Sanskrit Sansthan; Varanasi; Reprint 2010, Uttara Tantra 7/27-40 P. 44.

8. Khurana A k, Comprehensive Ophthalmology, Fourth edition, 2007, Jaypee. New Delhi P. 207.

9. Khurana A k, Comprehensive Ophthalmology, Fourth edition, 2007, Jaypee. New Delhi P. 90.

10. Khurana A k, Comprehensive Ophthalmology, Fourth edition, 2007, Jaypee. New Delhi P. 135.

11. Khurana A k, Comprehensive Ophthalmology, Fourth edition, 2007, Jaypee. New Delhi P 41

12. Khurana A k, Comprehensive Ophthalmology, Fourth edition, 2007, Jaypee. New Delhi P. 314.

13. Khurana A k, Comprehensive Ophthalmology, Fourth edition, 2007, Jaypee. New Delhi P. 321-322.

14. Khurana A k, Comprehensive Ophthalmology, Fourth edition, 2007, Jaypee. New Delhi P. 319.

15. Khurana A k, Comprehensive Ophthalmology, Fourth edition, 2007, Jaypee. New Delhi P. 29, 32.

16. Sashtri Ambika Dutta, Sushruta Samhita with Ayurve$d a$-Tattva-Sandipika Hindi commentary published by Chaukhambha Sanskrit Sansthan; Varanasi; Reprint 2010, Uttara Tantra 7/16-18, P.42. 
17. Khurana A k, Comprehensive Ophthalmology, Fourth edition, 2007, Jaypee. New Delhi P.303

18. Khurana A k, Comprehensive Ophthalmology, Fourth edition, 2007, Jaypee. New Delhi P.268.

19. Khurana A k, Comprehensive Ophthalmology, Fourth edition, 2007, Jaypee. New Delhi, P. 150.

20. Tripathy Brahmananda, Astanga Hridayam with Nirmala Hindi commentary, Chaukhamba Sanskrit Pratishthan; Delhi; Reprint 2017, Uttaratantra.12/23, P.963.

21. Sashtri AmbikaDutta, Sushruta Samhita with Ayurve$d a$-Tattva-Sandipika Hindi commentary published by Chaukhambha Sanskrit Sansthan; Varanasi; Reprint 2010, Uttara Tantra 17/55-56, P.82.

22. Sashtri AmbikaDutta, Sushruta Samhita with Ayurve$d a$-Tattva-Sandipika Hindi commentary published by Chaukhambha Sanskrit Sansthan; Varanasi; Reprint 2010, Uttara Tantra 17/63, P.83.

23. Tripathy Brahmananda, Astanga Hridayam with Nirmala Hindi commentary, Chaukhamba Sanskrit Pratishthan; Delhi; Reprint 2017, Uttaratantra.10/2225, P. 950.

24. Thakral K.K, Sushruta Samhita with Dalhana Nibandha Sangraha and Gayadas Nyaya Chandrika, Hindi Commentary, Published by Chaukhambha Orientalia, Varanasi, Reprint 2017, Uttara Sthana 5/7-8, (Dalhana Commentary) P. 22-23.

\section{Source of Support: Nil \\ Conflict of Interest: None Declared}

How to cite this URL: Tarun Kumar Dwibedi et al:Understanding The Concept Of Patala \& Drishti. International Ayurvedic Medical Journal \{online\} 2020 \{cited October, 2020\} Available from: http://www.iamj.in/posts/images/upload/4841_4846.pdf 